\title{
Factors Influencing the Adoption of Soil Erosion Control Technologies by Farmers along the Slopes of Mt. Elgon in Eastern Uganda
}

\author{
M. Barungi ${ }^{1,2}$, D. H. Ng'ong'ola ${ }^{1}$, A. Edriss ${ }^{1}$, J. Mugisha $^{3}$, M. Waithaka $^{4} \&$ J. Tukahirwa $^{5}$ \\ ${ }^{1}$ Department of Agricultural and Applied Economics, Faculty of Development Studies, Bunda College of \\ Agriculture, University of Malawi, Malawi \\ ${ }^{2}$ Economic Policy Research Centre, Plot 51, Makerere University, Kampala, Uganda \\ ${ }^{3}$ Department of Agribusiness and Natural Resource Economics, College of Agricultural and Environmental \\ Sciences, School of Forestry, Environmental and Geographical Sciences, Makerere University, Uganda \\ ${ }^{4}$ Association for Strengthening Agricultural Research in Eastern and Central Africa (ASARECA), Uganda \\ ${ }^{5}$ African Highlands Initiative (AHI), Uganda \\ Correspondence: Mildred Barungi, Economic Policy Research Centre, Plot 51, Makerere University, P.O. Box \\ 7841, Kampala, Uganda. Tel: 256-772-340-234. E-mail: mbarungi@eprc.or.ug
}

Received: September 4, 2012 Accepted: December 19, 2012 Online Published: January 10, 2013

doi:10.5539/jsd.v6n2p9

URL: http://dx.doi.org/10.5539/jsd.v6n2p9

\begin{abstract}
Low land productivity due to soil erosion is one of the biggest challenges to improving the performance of the agriculture sector in Uganda. Several soil erosion control technologies are recommended for use by farmers, but there have been claims that adoption of such technologies is still low. Therefore, this study aimed at determining factors that influence the incidence and intensity of technology adoption. A survey was conducted in Bukwo and Kween districts, which are located on the slopes of Mt. Elgon in eastern Uganda. The collected data was analysed using descriptive statistics and double hurdle models. The findings revealed that on average, the incidence of technology adoption is appreciably high and the intensity of use is moderately high. Nonetheless, a considerable percentage of farmers are using the technologies on small scale. We note that technology adoption can be further increased by increases in: access to extension services, amount of land owned, and diversity of farm tools owned by farmers. However, some farmers are not well endowed with regard to the agricultural assets and services alluded to. Thus, we recommend support to farmers by both Government and non-Government actors in line with the factors identified as potential catalysts of adoption of soil erosion control technologies.
\end{abstract}

Keywords: land productivity, soil erosion control, farmer support

\section{Introduction}

\subsection{Background}

For most Sub-Saharan African (SSA) countries, agriculture is crucial to achieving broad based pro-poor economic growth and attaining the Millennium Development Goal of halving poverty and hunger by 2015 , and continuing to reduce them thereafter (World Bank, 2007). This is because SSA countries heavily depend on agriculture. It is estimated that approximately $70-80 \%$ of employment and $40 \%$ of the Africa's export earnings are derived from agricultural activities (Food and Agriculture Organisation [FAO], 2006; International Monetary Fund [IMF], 2006).

In Uganda as well, agriculture is a core sector for economic growth, food security and nutrition, income enhancement, and employment. Although the sector's share in total Gross Domestic Product (GDP) has declined from over $50 \%$ in the early 1990 s to only $22.5 \%$ in $2010 / 11$, agriculture socially remains the most important sector because most Ugandans derive their livelihood from it. In 2009/10, the sector employed 66\% (8.8 million) of the working population and contributed approximately $46 \%$ of the total export earnings (Ministry of Agriculture, Animal Industry and Fisheries [MAAIF], 2011).

The contribution of agriculture to economic growth in SSA countries cannot be over emphasized. A well-performing agricultural sector is considered fundamental for Africa's overall economic growth, as well as addressing hunger, poverty, and inequality. The performance of the agriculture sector greatly depends on land 
productivity. However, in most SSA countries, agricultural productivity and production growth are low mainly because land in many areas is degraded (Association for Strengthening Agricultural Research in Eastern and Central Africa [ASARECA], 2004; Zimmermann et al., 2009). Land degradation is most problematic in highlands and it impairs the capacity of soils to support proper plant growth (Sanchez, 2002; Hellin, 2003; Pender et al., 2004; Sachs et al., 2004). It is estimated that 95 million hectares of land in eastern and central Africa have reached a state of degradation where only huge investments can make them productive again (Henao \& Baanante, 2006).

Land degradation has been one of the major global issues during the past years particularly because of its adverse impacts on agronomic productivity, the environment, food security and the quality of life. The economic impacts of land degradation have been very severe in some parts of Africa, where productivity has declined by $50 \%$ (Bellone et al., 2009). It has been reported by Lufumpa (2005) that severe land degradation in SSA has continued to threaten agricultural productivity and thereby undermine efforts to reduce poverty. Jansky and Chandran (2004) estimated that land degradation reduces the annual agricultural GDP of Africa by $3 \%$. The population in SSA is expected to double in the next 50 years, implying that there will be more demand for food (United Nations Population Fund [UNPF], 2007). Thus, unless corrective measures are taken now, there is likely to be a big food crisis in the SSA region.

Uganda is one of the countries with very high rates of land degradation in SSA. Land degradation in Uganda is widespread but varies in magnitudes from one part of the country to another depending on farming practices, population pressure, vulnerability of the soil to denudation and local relief (MAAIF, 2010). The worst affected areas are highlands of Kapchorwa, Bukwo, Kween and Mbale in Eastern Uganda, and Kabale and Kisoro in Western Uganda (Zake et al., 1999; Olson \& Berry, 2003). About $85 \%$ of land degradation in Uganda is accounted for by soil erosion and nutrient depletion (National Environmental Management Authority [NEMA], 2001). Land degradation is cited in the Agricultural Development Strategy and Investment Plan (ADSIP) of the country as one of the major constraints to increasing agricultural productivity and production (MAAIF, 2010).

In Uganda, detrimental impacts of land degradation are evident both at national and household levels, and some authors have attempted to quantify them. At the national level, the country was estimated to lose $4 \%$ to $12 \%$ of total GDP because of land degradation impacts (Slade \& Weitz, 1991). A decade later, the costs of land degradation were estimated to be 6-11\% of agricultural GDP annually. In 2003, NEMA estimated the annual cost of soil nutrient loss due primarily to erosion at about United States Dollars (USD) 625 million per year. In 2005, NEMA estimated that soil erosion alone accounted for over $80 \%$ of the annual cost of environmental degradation, representing as much as USD 300 million per year. Partly because of land degradation, crop yields at farm level are far below the attainable potential demonstrated by the National Agricultural Research Systems (MAAIF, 2010). The generally poor performance of the agriculture sector has in turn contributed to food insecurity and malnutrition. Indeed, Ssewanyana and Kasirye (2010) reported that 2 in every 3 Ugandans were food insecure.

In response to the devastating impacts of land degradation, the Government of Uganda (GoU) has formulated a number of natural resource management policies and passed several statutes at national level. Also, some districts and even lower administrative divisions have designed strategies and enacted bylaws to address the challenge of land degradation (Nkonya et al., 2005). Additionally, the Ministry of Agriculture, Animal Industry and Fisheries and some Non-Government Organisations (NGOs) such as the International Union of Conservation of Nature (IUCN), African Highlands Initiative (AHI), and Kapchorwa District Landcare Chapter (KADLACC) have been promoting the use of soil conservation technologies. The World Overview of Conservation Approaches and Technologies (WOCAT) defines soil conservation technologies as measures taken by farmers and other concerned Organisations to protect the soil and agricultural land from dangers such as erosion or degradation, and to conserve water resources.

In Uganda, technologies have been specifically promoted to help farmers control soil erosion because it is the major form of land degradation in highland areas (NEMA, 2001). They include: terraces, contours, trenches, agroforestry, and planting of Napier grass along contours and terraces. Mowo, Mwihomeke, and Mzoo (2002) provided evidence that farmers can increase their farm productivity by up to 5 times upon adoption of soil conservation technologies. Therefore, increasing the adoption of soil conservation technologies by farmers is a positive step towards increasing economic growth, especially in agrarian economies like Uganda.

\subsection{Statement of the Problem and Justification}

Despite the evident impacts of land degradation and efforts by Government and non-government organizations to promote use of soil erosion control technologies, uptake of these technologies by farmers is said to be still 
very low. According to the International Food Policy Research Institute (2007), adoption levels of soil and water conservation technologies ranged from as low as $2 \%$ to $17 \%$. This raises concern about sustainability of agricultural productivity; and it also means that the benefits associated with using soil conservation technologies are not yet fully exploited. The low adoption of soil conservation technologies perhaps explains why some authors (Kilewe \& Hatibu, 2004; Hatibu, 2005) have reported that land degradation in Uganda and other countries in eastern and central Africa not only persists, but is increasing at an alarming rate. Thus, the persistence of land degradation due to soil erosion is a big challenge to attainment of food security and substantially high incomes, especially among households that solely depend on agriculture. This study measured the incidence and intensity of adoption of soil erosion control technologies on the slopes of Mt. Elgon and established important factors that affect adoption. Findings from this study can be used by the Government of Uganda and development partners who are interested in solving the problem of land degradation so as to boost agricultural production.

\section{Relevant Related Literature}

\subsection{Development and Transfer of Soil Conservation Technologies}

Soil is a vital resource for crop production (Troeh et al., 1999) and so its productive capacity should be maintained through use of appropriate technologies. Through research several land management technologies have been developed to combat effects of land degradation. These technologies include: use of legumes in crop rotation, mulching, terracing, biomass transfer, contour bunds, and agro-forestry (Keely, 2001). This study focuses on soil erosion control technologies because soil erosion is the major form of land degradation in Uganda. The technologies used by farmers around Mt. Elgon to control soil erosion are: contours, terraces, trenches, and agroforestry and Napier grass for stabilising contours and terraces. These technologies are further elaborated on in the paragraphs that follow.

Contours are constructed across the slopes on cultivated land to reduce the erosive power of runoff flowing through the cultivated land. They reduce soil erosion by intercepting runoff and reducing its speed. In a study done in the United States by Ripley et al. (1961), it was reported that contours can reduce soil erosion on gentle slopes by 25 to $80 \%$. Trenches are dug along the contours to stop runoff, improve water infiltration and moisture storage capacity (Halmiton, 1997). Grass (such as Napier) and multipurpose trees can be planted along the contours to slow down runoff and catch sediments that have been eroded upslope. Planting vegetation along the contours and terraces stabilises the soil conservation structures, while contributing to improved productivity and biodiversity such as fodder, fuel wood, fruits and poles for building (Mati, 2005).

On sloping lands, terracing is necessary for reducing overland flow rates thereby contributing to water and nutrient conservation. Some of the common terracing technologies used by farmers in Uganda are fanya juu and bench terraces. Bench terraces are commonly made on steep slopes and they are labour intensive. For this reason, bench terraces are rarely excavated directly but instead they are developed over time from fanya juu terraces (Thomas, 1997). Fanya juu terraces are made by digging a drainage channel and throwing the soil upslope to make a ridge. Just like in the case of contours, grass and multipurpose trees can be planted on the ridges to help stabilise the ridges, prevent erosion and provide fodder and tree products (Thomas \& Biamah, 1991).

\subsection{A Review of Factors that Influence Adoption of Agricultural Technologies}

Adoption of agricultural technologies is affected by various factors, usually categorized into; farm specific characteristics, technology specific attributes, and farmer's socioeconomic characteristics. Examples of such variables that have been found to influence technology adoption include: farm size, farmer's age, education, social networks (e.g. membership of association), dependency ratio, gender, access to agricultural advice and information, land tenure security, soil fertility, soil type, income, input availability, access to markets, risk aversion behaviour, technology awareness, farming experience, adequacy of farm tools, technical and economic feasibility of using the technology, agro-ecological conditions, access to credit and presence of enabling policies (Feder et al., 1985; Manyong et al., 1999; Boyd \& Turton, 2000; Olwande et al., 2009). Some of these factors increase adoption; others reduce adoption; while others have mixed effects, as illustrated in the examples below.

Input and output uncertainties (regarding the costs of technology use and added benefits) are forms of risk that farmers face when deciding whether or not to adopt new technologies. Earlier studies (Moscardi \& de Janvry, 1977; Dillon \& Scandizzo, 1978; Binswanger, 1980; Antle, 1987) reported that farmers in developing countries are risk averse and therefore tend to delay the decision to adopt new technologies. According to these studies, even a small uncertainty related to changes in variable costs could make small and risk averse farmers to delay the decision to adopt a new agricultural technology. 
Farm size and land endowments also affect adoption either positively or negatively. In some empirical studies, a positive relationship between adoption and farm size is often found when food security is not a binding constraint or when there are fixed transaction and information acquisition costs associated with the new technology, therefore preventing smaller farms to engage in innovation (Feder \& O'mara, 1981; Feder et al., 1985). Households with large farms can choose to apply a given technology widely and there by reap economies of size (Langyintuo \& Mungoma, 2008). Yirga (2006) found that in Ethiopia, plot size positively and significantly affected both the likelihood of adoption and intensity of technology use. Similarly, Nakhumwa (2004) found that the adoption of marker ridging technique was positively influenced by land size. Other studies (Harper et al., 1990; Yaron, Dinar, \& Voet, 1992), however, have found a negative relationship between farm size and technology adoption, mostly due to farmers' risk aversion and their tendency to follow a technological ladder in adoption.

\section{Methodology}

\subsection{The Study Area}

This study was conducted in Eastern Uganda, in selected districts around the slopes of Mt. Elgon. The slopes of Mt. Elgon are characterised by high and well distributed rainfall (average of 1,200 mm/year), high altitude (700 to 2,800 metres above sea level) and cool temperatures, and relatively fertile volcanic soils (Nkonya et al., 2008). Kween and Bukwo districts were selected because, in these two districts, highlands cover about $37 \%$ of the total land area. Additionally, farmers in this area experience severe soil erosion associated with the steep rugged nature of the terrain and the problem is aggravated by heavy rains (Ministry of Finance, Planning and Economic Development [MFPED], 2000).

\subsection{Sampling Procedure}

A multi-stage (five stages) sampling procedure involving a combination of purposeful and random sampling procedures was used to draw a representative sample of farmers. The first step involved purposive selection of the two districts (Bukwo \& Kween) - where the problem of soil erosion is very severe and so the use of soil erosion control technologies is highly recommended. The next three steps involved random selection of 3 sub-counties per district, 2 parishes per sub-county and 2 villages per parish. Thus, in total 6 sub-counties, 12 parishes and 24 villages were selected for this study. The fifth (final) stage was the simple random sampling of farmers from the selected villages. To facilitate this final stage, lists of names of households in each selected village were obtained from the Local Council I Chairpersons. The names were assigned numbers and using a table of random numbers, 10 farmers from different households were selected from each selected village, hence, giving a total of 240 respondents.

\subsection{Data Sources, Tools and Methods of Collection}

As alluded to in the previous section, primary data were collected from the 240 randomly selected farmers using a semi-structured questionnaire and through face-to-face interviews. The interviews were conducted during the months of March and April in 2011. A semi-structured questionnaire was used because according to Fowler (1998) it is an effective tool for minimizing bias and random error. Moreover, a semi-structured questionnaire allows the researcher to prompt and probe deeper into the given situation. In addition, the researcher can explain or rephrase the questions if respondents are unclear about the questions. The data was largely based on farmers' memory recall, because, in Uganda, keeping of records is not a regular practice among smallholder farmers. Data collected included: technologies adopted by farmers to control soil erosion, proportions of cultivated land that were under soil erosion control technologies, farmer specific characteristics like age and years of formal schooling, institutional factors such as access to credit and extension services, and farm characteristics such as size and location of cultivated land on the mountain slopes.

\subsection{Data Analysis Techniques}

This section presents the different approaches that were used to analyse data in line with the specific study objectives. Data were analysed through generation of descriptive statistics and estimation of double-hurdle models. The data were analysed using STATA (Stata Corp, 2011). The different analytical approaches are further discussed below.

\subsubsection{Descriptive Analysis}

The incidences and intensity of adoption of soil erosion control technologies were described using percentages, means and standard deviations. 


\subsubsection{Theoretical Models for Analysing Technology Adoption}

This section provides different approaches that can be used to analyse adoption decisions. The choice of an appropriate model is determined by the nature of the dependent variable, as indicated in the discussion herein.

Limited dependent variable models such as the linear probability model (LPM), Logit and Probit are used when the dependent variable is dichotomous. According to Wooldridge (2009), the linear probability model is estimated by ordinary least squares (OLS) technique, and allows us to explain a binary response using regression analysis. The OLS estimates in the LPM are interpreted as changes in the probability of "occurrence" (dependent variable takes on a value of 1), given a unit increase in the corresponding explanatory variable. Two most important disadvantages of the LPM are that the fitted probabilities can be less than zero or greater than one and the partial effect of any explanatory variable is constant. These limitations can be overcome by using either Logit or Probit models.

Logit and Probit models investigate the effects of regressors on the choice to use or not to use a technology. These models are statistically similar (Amemiya, 1981), except that the Probit model assumes a normal cumulative distribution function (thus has fatter tails) while the Logit model assumes a logistic distribution of the dependent variable. Although parameter estimates may differ in the two models because the two distributions have different scales, Amemiya (1981) and Agresti (2002) noted that it would require enormous sample sizes to have significant differences in the two models. Use of either model is thus discretionary. Variants of the Logit model include the ordinary Logit (binary Logit), the ordinal logistic, nominal logistic and the multinomial Logit. The ordinal logistic regression model is used when the dependent variable is ordered while nominal logistic handles nominal categorical responses. Multinomial logistic modelling is a special case of ordinary logistic approach, developed to address the case where the dependent variable can take on more than two values that are not ordered. Unlike Logit models, probit models lack flexibility - they do not easily incorporate more than one prediction variables (Montgomery et al., 2001)

One biggest shortcoming of the Logit and Probit models is that they do not measure the degree or intensity of technology adoption (Feder et al., 1985). The alternative econometric model that can be used to analyse intensity of adoption (such as percent of area planted to improved crop varieties and amount of fertilizer applied) is the Tobit model. This model can be used to analyse the dependent variable where some data points can be zero or censored (information is missing for some range of the sample). However, the Tobit model imposes restrictions that the variables and coefficients determining whether and how much to adopt decisions are identical. Yet, earlier studies (Cragg, 1971; Coady, 1995) indicated that such decisions might not be intimately related. The alternative to analyse farmers' adoption decisions is to use Double hurdle models such as the Heckman model, Double - limit hurdle model; and the two-stage combination of the Probit and Truncated regression models.

\subsubsection{Empirical Model Used to Analyse Adoption-Double-Hurdle Model}

The double-hurdle model was used to analyse the determinants of both incidences and intensity of adoption of soil erosion control technologies. This model was chosen because it assumes that households make two sequential decisions with regard to adopting technologies. Each hurdle is conditioned by the farmer's socio-economic characteristics and technology-specific attributes. In estimating the double-hurdle model, a probit regression (using all observations) is followed by a truncated regression on the non-zero observations (Cragg, 1971).

The double-hurdle model is designed to analyse instances of an event which may or may not take place and if it takes place, takes on continuous values. In the case of farmer adoption of soil erosion control technologies (contours, terraces, trees, Napier grass, and trenches), a decision on adopting each technology is made first, and then the decision on the intensity of use (percentage of cultivated land under a technology or set of technologies) follows. A different latent variable is used to model each decision process, with a probit model to determine the probability that a household will adopt a soil erosion control technology and a truncated regression model to determine the intensity of adoption. Thus, the model is specified in two separate parts as indicated in Equations 1 and 2 .

$$
\begin{aligned}
& \text { Probit model: } y_{i 1}^{*}=w_{i}^{\prime} \alpha+v_{i} \text { (decision to use a soil erosion control technology) } \\
& y_{i 2}^{*}=x_{i}^{\prime} \beta+\mu_{i} \text { (intensity of technology use for } y_{i 2}^{*}>0 \text { ) } \\
& \text { Truncated regression model: } y_{i}=x_{i}^{\prime} \beta+\mu_{i} \text { if } y_{i 1}^{*}>0 \text { and } y_{i 2}^{*}>0
\end{aligned}
$$

Where $y_{i 1}^{*}$ is a latent variable describing the farmer's decision to adopt a soil erosion control technology, $y_{i 2}^{*}$ a latent variable describing the intensity of adoption, and $y_{i}$ is the observed dependent variable or the actual percentage of cultivated land under a technology or set of technologies. $w_{i}$ and $x_{i}$ are vectors of variables explaining the adoption and use intensity, respectively, while $v_{i}$ and $\mu_{i}$ are the respective error terms assumed 
to be independent and normally distributed as $v_{i} \sim N(0,1)$; and $\mu_{i} \sim N\left(0, \delta^{2}\right)$. The expected value of the latent variable is $E y_{i}^{*}=x_{i}^{\prime} \beta$. Observation $i$ is only observed if $y_{i}^{*}$ is above a certain known threshold, which is zero in this case.

The probability density function (pdf) of the observed truncated variable $y_{i}$ is therefore, the pdf of the latent variable conditional on it being observed (Equation 3)

$$
f\left(y_{i} \mid x_{i}\right)=f\left(y_{i}^{*} \mid y_{i}^{*}>0, x_{i}\right)=\frac{f\left(y_{i}^{*} \mid x_{i}\right)}{p\left(y_{i}^{*}>0 \mid x_{i}\right)}=\frac{\sigma^{-1} \phi\left(\frac{y_{i}-x_{i}^{\prime} \beta}{\sigma}\right)}{1-\Phi\left(\frac{0-x_{i}^{\prime} \beta}{\sigma}\right)}=\frac{1 \phi\left(\frac{x_{i}^{\prime} \beta-y_{i}}{\sigma}\right)}{\sigma \Phi\left(\frac{x_{i}^{\prime} \beta}{\sigma}\right)}
$$

When estimating the truncated regression model, the simple linear regression of the observed variable $y_{i}$ on $x_{i}$ would yield biased estimates of beta, as the error term would be correlated with the independent variables (Heteroskedasticity). Allowing for Heteroskedasticity and a non-normal error structure (Jensen and Yen, 1996; Yen and Jones, 1997), the truncated regression model is estimated using maximum likelihood of the form:

$$
L(\alpha, \beta, h, \theta)=\Pi_{0}\left[1-\Phi\left(w_{i}^{\prime} \alpha\right) \Phi\left(\frac{x_{i}^{\prime} \beta}{\sigma_{i}}\right)\right] \times \Pi_{1}\left[\left(1+\sigma^{2} y_{i}^{2}\right)^{-1 / 2} \Phi\left(w_{i}^{\prime} \alpha\right) \sigma_{i}^{-1} \emptyset\left(\frac{T\left(\theta y_{i}\right)-x_{i}^{\prime} \beta}{\sigma_{i}}\right)\right]
$$

To assess the impact of the regressors on the extent of adoption, it is necessary to analyse the marginal effects of the selected variables. According to Jensen and Yen (1996), and Yen and Jones (1997), the intensity of adoption conditional on adoption is computed as

$$
E\left(y_{i} \mid y_{i}>0\right)=\Phi\left(\frac{x_{i}^{\prime} \beta}{\sigma_{i}}\right)^{-1} \int_{0}^{\infty}\left(\frac{y_{i}}{\sigma_{i} \sqrt{1+\sigma^{2} y_{i}^{2}}} \varnothing\left(\frac{T\left(\theta y_{i}\right)-x_{i}^{\prime} \beta}{\sigma_{i}}\right)\right) \partial y_{i}
$$

Where $\varnothing$ and $\Phi$, respectively are the probability density function and the cumulative density function of the standard normally distributed random variable.

To adopt or not to adopt a technology is often a discrete choice. Both the probit and Logit models can be used to analyse such a dependent variable. It is often difficult to choose between the two models owing to their statistical similarities. However, according to Atemnkeng, Boboh, and Kenyi (2010), the probit specification has an edge over the Logit model in the case of small sample sizes (less than 1000 observations). Thus, with a sample size of 240 farmers, the present study employed a probit model to examine determinants of farmers' decision to use or not to use soil erosion control technologies.

Diagnostic tests were run before estimating the double hurdle model in order to establish whether there was any significant correlation between any two independent variables; and to eliminate highly correlated independent variables before the actual procedure of econometric analysis. The diagnostic tests alluded to were necessary because the effect of the regressor inter-correlation causes the regression coefficients generated to be unstable due to high variance, and so it becomes extremely difficult to isolate the contribution of specific independent variables to the variation of the dependent variable (Greene, 1997). Consequently, the coefficients for the theoretically specified independent variables become insignificant or come up with signs opposite the ones expected from theory and/or previous studies. All the explanatory variables described in Table 1 were found to be independent except land size and the estimated annual income. As such, in estimating the econometrics models, the income variable was dropped to avoid getting biased estimates emanating from multicollinearity. Income was dropped based on the assumption that farmers are more likely to give realistic estimates of their land sizes compared to income estimates. To eliminate skewness and kurtosis, all continuous variables were subjected to gladder command in STATA and transformed accordingly to normalize them. For all the estimated models, robust standard errors were generated because they account for Heteroskedasticity.

\section{Results and Discussions}

This section presents the descriptive statistics and results of the double hurdle model that was used to analyse adoption of soil erosion control technologies.

\subsection{Descriptive Statistics for Farmers, Farms and Technology Specific Attributes}

According to the descriptive statistics presented in Table 1, most (82\%) survey respondents were men. Majority (94\%) were married and a few others had either separated from their spouses or were widowed. The mean age of the surveyed farmers was about 40 years. On average, 4 members in each represented household were aged between 13 and 65 years - according to the Uganda Bureau of Statistics (UBoS) people in this age group are the ones considered to be economically active. In the context of this study, the number of economically active people in a household represents the size of the potential family agricultural labour force. Almost all (98\%) farmers had ever attended school. However, close to $47 \%$ of the farmers only attained primary education. A 
remarkable proportion (38.5\%) of farmers studied up to secondary level. Only $12.6 \%$ of the farmers obtained tertiary education from vocational training institutes $(9.6 \%)$ and Universities (3\%). Level of education aside, the mean number of years of formal schooling completed was as low as 8.5 years.

Table 1. Description and summary statistics of variables used in econometric analysis

\begin{tabular}{|c|c|c|c|c|}
\hline Variable name & Variable description & Measure & Mean & $\begin{array}{l}\text { Std } \\
\text { Dev }\end{array}$ \\
\hline \multicolumn{5}{|l|}{ Dependent variables } \\
\hline Adopted_technology & Farmer has adopted at least one technology & $1=$ Yes, $0=$ No & 0.91 & 0.29 \\
\hline Adopted_Contours & Farmer has made contours & $1=$ Yes, $0=$ No & 0.57 & 0.5 \\
\hline Adopted_Napier & Farmer has planted Napier grass & $1=$ Yes, $0=$ No & 0.47 & 0.5 \\
\hline Adopted_trees & Farmer has planted trees & $1=\mathrm{Yes}, 0=\mathrm{No}$ & 0.44 & 0.5 \\
\hline Adopted_trenches & Farmer has dug trenches & $1=$ Yes, $0=$ No & 0.37 & 0.48 \\
\hline Adopted_terraces & Farmer has made terraces & $1=\mathrm{Yes}, 0=\mathrm{No}$ & 0.3 & 0.46 \\
\hline Adoption_intensity1 & Number of technologies a farmer is using & Count & 2.36 & 1.16 \\
\hline Adoption_intensity2 & $\begin{array}{l}\text { Percentage of cultivated land that is under soil } \\
\text { erosion control technologies }\end{array}$ & Percentage & 68.77 & 31.91 \\
\hline \multicolumn{5}{|l|}{ Regressors } \\
\hline Age & Number of years lived by the farmer & Years & 38.93 & 12.44 \\
\hline School_years & Number of formal schooling years completed & Years & 8.54 & 3.57 \\
\hline Family_labour & $\begin{array}{l}\text { Potentially available family labour force (household } \\
\text { members aged between } 13 \text { and } 65 \text { years) }\end{array}$ & Count & 3.75 & 1.88 \\
\hline Land_owned & Size of land owned by the farmer & Hectares & 1.09 & 1.88 \\
\hline Annual_income & Estimated average income earned annually & $\begin{array}{l}\text { Million } \\
\text { Shillings }\end{array}$ & 1.38 & 1.97 \\
\hline Farm_tools & Number of different types of farm tools owned & Count & 3.34 & 1.59 \\
\hline Extension_visits & Number of extension visits received & Count & 1.68 & 1.95 \\
\hline Farming_hours & Number of hours spent daily on farm activities & Count & 5.84 & 1.83 \\
\hline Sex & Sex of the farmer & $\begin{array}{l}1=\text { Male } \\
0=\text { Female }\end{array}$ & 0.82 & 0.39 \\
\hline Marital_status & Marital status & $\begin{array}{l}1=\text { Married } \\
0=\text { Otherwise }\end{array}$ & 0.94 & 0.24 \\
\hline Main_occupation & Main economic activity & $\begin{array}{l}1=\text { Farming } \\
0=\text { Salaried job }\end{array}$ & 0.9 & 0.3 \\
\hline Credit_access & Needed credit and was able to get it & $1=$ Yes, $0=$ No & 0.16 & 0.36 \\
\hline \multicolumn{5}{|c|}{ Highest level of education attained } \\
\hline Educ_level $_{1}$ & Primary education and below & $1=$ Yes, $0=$ No & 0.49 & 0.5 \\
\hline Educ_level $_{2}$ & Secondary education & $1=$ Yes, $0=$ No & 0.39 & 0.49 \\
\hline Educ_level $_{3}$ & Tertiary or vocational training (including University) & $1=$ Yes, $0=$ No & 0.13 & 0.33 \\
\hline \multicolumn{5}{|c|}{ Location of the farmland along the slopes of Mt. Elgon } \\
\hline Downslope & Land cultivated is at the bottom of the slope & $1=\mathrm{Yes}, 0=\mathrm{No}$ & 0.2 & 0.4 \\
\hline Mid-slope & $\begin{array}{l}\text { Land cultivated is mid-way between the bottom and } \\
\text { the top of the slope }\end{array}$ & $1=$ Yes, $0=$ No & 0.38 & 0.49 \\
\hline Upslope & Land cultivated is within the top section of the slope & $1=$ Yes, $0=$ No & 0.35 & 0.48 \\
\hline Multiple_locations & $\begin{array}{l}\text { Land cultivated is in multiple locations along the } \\
\text { slope }\end{array}$ & $1=\mathrm{Yes}, 0=\mathrm{No}$ & 0.07 & 0.25 \\
\hline
\end{tabular}


Table 1. Description and summary statistics of variables used in econometric analysis (continued)

\begin{tabular}{|c|c|c|c|c|}
\hline Variable name & Variable description & Measure & Mean & $\begin{array}{l}\text { Std } \\
\text { Dev }\end{array}$ \\
\hline \multicolumn{5}{|c|}{ Soil fertility of the farmland as perceived by the farmer } \\
\hline Not_fertile & Soils cultivated are not fertile & $1=$ Yes, $0=$ No & 0.11 & 0.32 \\
\hline Moderate_fertility & Soils cultivated are moderately fertile & $1=$ Yes, $0=$ No & 0.65 & 0.48 \\
\hline Fertile & Soils cultivated are fertile & $1=$ Yes, $0=$ No & 0.24 & 0.43 \\
\hline \multicolumn{5}{|c|}{ Distance to markets } \\
\hline Short_mktdist & $\begin{array}{l}\text { Distance from farmer's home to the nearest market is } \\
\leq 1 \mathrm{~km}\end{array}$ & $1=$ Yes, $0=$ No & 0.49 & 0.5 \\
\hline Medium_mktdist & $\begin{array}{l}\text { Distance from farmer's home to the nearest market is } \\
\text { over } 1 \mathrm{~km} \text { but does not exceed } 3 \mathrm{~km}\end{array}$ & $1=$ Yes, $0=$ No & 0.19 & 0.39 \\
\hline Long_mktdist & $\begin{array}{l}\text { Distance from farmer's home to the nearest market is } \\
\text { beyond } 3 \mathrm{~km} \text { radius }\end{array}$ & $1=$ Yes, $0=$ No & 0.33 & 0.47 \\
\hline \multicolumn{5}{|c|}{ Awareness of costs and benefits of technology } \\
\hline Contour_BC & Knows the costs and benefits of using contours & $1=\mathrm{Yes}, 0=\mathrm{No}$ & 0.69 & 0.47 \\
\hline Napier_BC & $\begin{array}{l}\text { Knows the costs and benefits of planting Napier grass } \\
\text { along contours/terraces. }\end{array}$ & $1=$ Yes, $0=$ No & 0.7 & 0.46 \\
\hline Tree_BC & $\begin{array}{l}\text { Knows the costs and benefits of planting trees along } \\
\text { contours/terraces. }\end{array}$ & $1=\mathrm{Yes}, 0=\mathrm{No}$ & 0.66 & 0.48 \\
\hline Trench-BC & $\begin{array}{l}\text { Knows the costs and benefits of digging trenches on } \\
\text { farmland }\end{array}$ & $1=$ Yes, $0=$ No & 0.67 & 0.47 \\
\hline Terrace_BC & $\begin{array}{l}\text { Knows the costs and benefits of making terraces on } \\
\text { the farmland }\end{array}$ & $1=$ Yes, $0=$ No & 0.46 & 0.5 \\
\hline
\end{tabular}

In terms of land ownership, the mean landholding was estimated at 1.1 hectares. However, most farmers (over $90 \%$ ) owned less than 1.1 hectares - this is a clear manifestation of high inequality in land ownership. Some of the farmers who own very little land were forcefully evicted from Mt. Elgon National Park by the Uganda Wildlife Authority while restoring the park's colonial boundaries. Government has already resettled some households but others are yet to be resettled in areas outside the park (World Rainforest Movement's Bulletin No. 131, June 2008). Looking at the diversity of farm tools owned, it was noted that on average each household had three different types of farm tools (such as hoes, ploughs, oxen, and wheelbarrows). It should be noted though, that a considerable percentage (about $32 \%$ ) of the farmers owned at most two types of tools. The mean annual household income was estimated at 1.38 million Uganda shillings but only $31.8 \%$ of the farmers had incomes exceeding this mean. This finding serves to emphasize the existence of income inequality not only in urban areas but also in rural areas as often reported by the Uganda Bureau of Statistics. Many (90\%) respondents were doing farming as their primary (main) source of livelihood. On average, each farmer spent about 6 hours daily on farming activities (such as land preparation, planting, fertilizer application, weeding, and harvesting). Slightly over $23 \%$ reportedly spent more than 6 hours daily on farm related activities.

More than half of the respondents $(56 \%)$ had received extension services at least once during the past two years. The mean number of extension visits per farmer was extremely low (about 1 visit per year - yet there are two cropping seasons in a year). This means that delivery of extension services to farmers is not regular. Farmers reportedly received advice and training in several areas including: sustainable land management, agro-enterprise diversification, crop and livestock management, group formation and planning, among others. Many farmers (about 42\%) accessed extension services from the National Agricultural Advisory Services (NAADS) program and other Government agricultural officers. The second most important source of extension services was farmer groups/associations - accessed by $24 \%$ of the farmers. Some farmers $(15 \%)$ accessed extension services from Non-Government Organisations such as Kapchorwa District Landcare Chapter (KADLACC), African Highland Initiative (AHI), International Union for Conservation of Nature (IUCN), Grameen Foundation, and ActionAid. Very few $(16 \%)$ farmers reportedly had access to financial credit - they obtained loans whenever they needed extra money to finance their farming operations.

Most (93\%) farmers were cultivating land located in only one particular section of the mountain slope - either downslope or middle section or upslope. Along the slopes, $38 \%$ of the farmers have their farm lands in the middle section; $35 \%$ at the very top (upslope); $20 \%$ at the bottom (downslope); and about $7 \%$ of the all interviewed farmers had land fragments in two or all the three sections of the mountain slopes. Farmers were asked to give their perceptions about the fertility of the land they cultivate. Soil fertility was categorised into 3 
based on qualitative measures namely: 1) The land does not require use of soil and water conservation (SWC) technologies but can perhaps do better with minimal use of SWC technologies - "fertile"; 2) the land requires regular use and maintenance of SWC technologies - "moderately fertile"; and 3) the land cannot produce anything unless SWC technologies are used - "not fertile". Accordingly, many (about 65\%) farmers perceived their soils to be moderately fertile; $24 \%$ were of the view that their soils were fertile; and $11 \%$ said their soils were not fertile.

Farmers were also asked about the costs involved in establishing and maintaining soil erosion control structures (contours, terraces and trenches) and vegetative measures (Napier grass and trees). Additionally, they were asked to elucidate the benefits associated with the use of each of the five technologies. Approximately $70 \%$ of the farmers knew the costs and benefits of planting Napier grass along contours and terraces. About $69 \%$ of the farmers reportedly knew the costs and benefits associated with the use of contours. Many (67\%) farmers had knowledge of the costs and benefits associated with digging trenches. An appreciable percentage $(66 \%)$ of farmers could explain the costs and benefits of planting trees along contours and terraces. Relatively fewer farmers (46\%) said they knew the costs and benefits of using terraces.

\subsection{Incidence and Intensity of Technology Adoption}

Most (about 91\%) farmers have adopted soil erosion control technologies. However, some adopters (27.5\%) were using just one type of technology on their farms - either contours or terraces or trenches, or Napier grass or trees. Usually on most cultivated lands, use of one type of technology is necessary but not sufficient to control soil erosion. Therefore, farmers are advised to combine several technologies. Indeed, there are farmers who were combining a set of technologies. The mean number of technologies used by each adopter was 2 technologies. Close to $73 \%$ of adopters were combining 2 or more technologies. There are over 20 ways in which farmers were combining and applying soil erosion control technologies but the five commonest ways were: contours + Napier grass $(10.6 \%$ adopters); contour + terraces + trenches + Napier grass + trees $(7 \%$ adopters $)$; contours + Napier grass + trenches $(6.4 \%$ adopters); contours + Napier grass + trees $(6.4 \%$ adopters $)$; and contour + trenches + Napier + trees $(5.5 \%$ adopters). Generally, contours were the most adopted $(57.3 \%)$ soil erosion control structures. Over $47 \%$ and $43 \%$ of farmers had planted Napier grass and were practicing agroforestry, respectively. Digging trenches was the second least adopted technology and was practiced by about $37 \%$ of the farmers. Terraces were the least adopted structures and only $30 \%$ of the farmers had terraced farmlands. During the survey, farmers reported that making terraces and digging trenches is labour intensive, and this makes the two technologies less attractive. Indeed, Kashay (2011) reported that labour intensive physical structures for soil and water conservation are less likely to be adopted by households, especially those that are labour constrained and have no financial capacity to outsource hired labour.

The mean proportion of cultivated land to which the technologies are applied is about $69 \%$ and actually half of the farmers were applying these technologies on over $70 \%$ of their total cultivated land. Nonetheless, it should be noted that about $34 \%$ of the farmers were applying soil erosion control technologies on $\leq 50 \%$ of their cultivated lands. This means that degree of uptake of soil erosion control technologies is not uniform among farmers and in some cases it is very low, hence the need for more effort geared towards intensification of these technologies. However, the generally high incidences and intensities of adoption of the soil erosion control technologies indicate that to some extent, farmers do appreciate the seriousness of soil erosion and the implications on agricultural land productivity. Although the percentage of farmers who have not adopted any soil erosion control technology is low (about 9\%), adoption should be further encouraged because actions of non-adopters sometimes have spill over effects - negative externalities. Such effects include soil erosion caused by un-intercepted runoff flowing through the fields of adopters. Indeed, Garry (2000) reported that use of soil conservation technologies by just some farmers may not effectively control soil erosion because of negative externalities caused by actions of non-adopters.

\subsection{Determinants of Adoption of Contours}

As shown in Table 2, the Probit model for analysing incidence of contour adoption is statistically significant at $5 \%$, implying that the model is generally a good fit for the data. Two factors namely: doing farming as the main economic activity and having many different types of farm tools were found to have significant positive effects on the decision to adopt contours. The probability of adopting contours is $36.7 \%$ higher for farmers who do farming as their main economic activity than for those who mainly depend on salaried jobs. The marginal effect of the square root of the number of types of farm tools owned is 0.144 and is statistically significant at $10 \%$ level. This means that every additional unit of the square root of the number of types of farm tools (above the mean number of types of tools - 3 types), increases the probability of adopting contours by $14.4 \%$. We would therefore, 
expect that every unit increase in the types of farm tools will also affect contour adoption positively and significantly. The plausible explanation to this finding is that to make contours, a farmer requires different types of farm tools such as an A-frame, wooden pegs, a panga, a hoe, and sisal strings, among others. In a related study, Boyd et al. (2000) reported that the use of soil conservation technologies imposes a high demand on farm tools. Unfortunately, in Bukwo and Kween districts, few farmers (38\%) own more than three different types of farm tools. Therefore, when promoting the use of contours, complementary efforts should be made to ensure that farmers acquire an assortment of the required farm tools.

On the negative side, only one factor was found to significantly reduce the probability of adopting contours farmer's perception that cultivated soils are moderately fertile. The probability of adopting contours was estimated to be about $22 \%$ less for farmers with a perception that their soils are moderately fertile than for those who perceive their soils as fertile. This means that farmers who think their soils are moderately fertile are not putting measures in place to conserve the fertility. This certainly points out the need for further provision of agricultural extension services.

\subsection{Determinants of Adoption of Terraces}

The model estimated to identify the determinants of adoption of terraces was statistically significant at $1 \%$, an indication that it is a good fit. Results revealed that adoption of terraces is positively and significantly influenced by: sex of the farmer; downslope and mid-slope locations of cultivated land on the mountain slopes; and the perception that cultivated soils are not fertile (Table 2). The estimates of marginal effects indicate that the probability that a male farmer will adopt terraces is $26.4 \%$ higher than that of a female farmer. The probability of adopting terraces is about $18 \%$ higher for farmers whose farmlands are downslope than for those whose farms are upslope. Similarly, the probability of adopting terraces is about $14 \%$ higher for farmers whose farmlands are mid-slope than for those whose farms are upslope. The probability of adopting terraces is $24.5 \%$ higher for farmers with a perception that their soils are not fertile than for those who perceive their soils as fertile. We would expect that farmlands upslope are more prone to soil erosion and therefore use of erosion control technologies is paramount. Similarly, since land is a scare resource, farmers with soils that are not fertile definitely need to take measures to rejuvenate the soil fertility and maintain it thereafter. Thus, we note a need for targeted extension advice especially to farmers doing farming upslope and those with soils that are already degraded.

\subsection{Determinants of Adoption of Trenches}

The probit model estimated to identify important factors that influence adoption of trenches is a good fit $\left(\right.$ Prob $\left.>\mathrm{chi}^{2}=0.006\right)$. The following factors were found to have positive and statistically significant effect on the adoption of trenches: access to extension services; ownership of different types of farm tools; age; and relatively long distance to markets $(>3 \mathrm{~km})$. According to the marginal effects estimates, the probability of adopting trenches is $13 \%$ higher for farmers with access to extension services than for those without access. Every additional unit of the square root of the number of types of farm tools (above the mean number of types of tools 3 types), increases the probability of adopting trenches by $26 \%$. Thus, it is expected that every unit increase in the types of farm tools will also affect adoption of trenches positively and significantly. Unexpectedly, the probability of adopting trenches is $14.7 \%$ higher for farmers residing $>3 \mathrm{~km}$ away from markets compared with farmers who are within $1 \mathrm{~km}$ away. The study identified sex of the farmer and the perceptions about soil fertility as the important factors that affect adoption of trenches negatively. Specifically, the probability that a male farmer will adopt trenches is about $23 \%$ lower than that of a female farmer.

The probability of adopting trenches is about $24 \%$ lower for farmers with a perception that their soils are not fertile than for those who perceive their soils as fertile. Similarly, the probability of adopting trenches is $17.5 \%$ lower for farmers with a perception that their soils are moderately fertile than for those who perceive their soils as fertile. This means that there is need to provide targeted extension services to men and farmers with less fertile soils on the need to dig trenches to intercept runoff and control soil erosion. 
Table 2. Relative importance of factors that affect farmers' decisions regarding adoption of soil erosion control technologies

\begin{tabular}{|c|c|c|c|c|c|}
\hline & \multicolumn{5}{|c|}{ Marginal Effects and Robust Standard Errors (in parenthesis) } \\
\hline & Contours & Terraces & Trenches & Trees & $\begin{array}{l}\text { Napier } \\
\text { grass }\end{array}$ \\
\hline Years of formal schooling & $\begin{array}{l}0.002 \\
(0.011)\end{array}$ & $\begin{array}{l}0.005 \\
(0.010)\end{array}$ & $\begin{array}{l}-0.010 \\
(0.011)\end{array}$ & $\begin{array}{l}0.007 \\
(0.011)\end{array}$ & $\begin{array}{l}0.012 \\
(0.012)\end{array}$ \\
\hline lnAge (years) & $\begin{array}{l}-0.023 \\
(0.113)\end{array}$ & $\begin{array}{l}-0.037 \\
(0.102)\end{array}$ & $\begin{array}{l}0.190 \\
(0.109)^{*}\end{array}$ & $\begin{array}{l}0.106 \\
(0.118)\end{array}$ & $\begin{array}{l}0.108 \\
(0.122)\end{array}$ \\
\hline lnNumber of adults in a household & $\begin{array}{l}-0.030 \\
(0.079)\end{array}$ & $\begin{array}{l}-0.062 \\
(0.071)\end{array}$ & $\begin{array}{l}-0.094 \\
(0.080)\end{array}$ & $\begin{array}{l}-0.102 \\
(0.084)\end{array}$ & $\begin{array}{l}0.131 \\
(0.089)\end{array}$ \\
\hline $\begin{array}{l}\text { sqrtNumber of different types of farm tools } \\
\text { owned }\end{array}$ & $\begin{array}{l}0.144 \\
(0.080)^{*}\end{array}$ & $0.056(0.068)$ & $\begin{array}{l}0.262 \\
(0.093)^{* * *}\end{array}$ & $\begin{array}{l}0.176 \\
(0.074)^{* *}\end{array}$ & $\begin{array}{l}0.418 \\
(0.099)^{* * *}\end{array}$ \\
\hline lnNumber of daily farming hours & $\begin{array}{l}-0.058 \\
(0.097)\end{array}$ & $\begin{array}{l}0.010 \\
(0.082)\end{array}$ & $\begin{array}{l}-0.103 \\
(0.094)\end{array}$ & $\begin{array}{l}-0.207 \\
(0.101)^{* *}\end{array}$ & $\begin{array}{l}-0.142 \\
(0.097)\end{array}$ \\
\hline InSize (hectares) of land owned & $\begin{array}{l}0.022 \\
(0.043)\end{array}$ & $\begin{array}{l}0.012 \\
(0.040)\end{array}$ & $\begin{array}{l}-0.004 \\
(0.041)\end{array}$ & $\begin{array}{l}0.082 \\
(0.043)^{*}\end{array}$ & $\begin{array}{l}-0.025 \\
(0.047)\end{array}$ \\
\hline Sex $(1=$ Male, $0=$ Female $)$ & $-0.014(0.091)$ & $\begin{array}{l}0.264 \\
(0.054)^{* * *}\end{array}$ & $\begin{array}{l}-0.228 \\
(0.095)^{* *}\end{array}$ & $\begin{array}{l}-0.095 \\
(0.089)\end{array}$ & $\begin{array}{l}-0.219 \\
(0.097)^{* *}\end{array}$ \\
\hline $\begin{array}{l}\text { Access to extension services }(1=\text { Access, } 0=\text { No } \\
\text { access })\end{array}$ & $\begin{array}{l}0.062 \\
(0.068)\end{array}$ & $\begin{array}{l}0.066 \\
(0.062)\end{array}$ & $\begin{array}{l}0.131 \\
(0.067)^{*}\end{array}$ & $\begin{array}{l}0.077 \\
(0.069)\end{array}$ & $\begin{array}{l}0.256 \\
(0.071)^{* * * *}\end{array}$ \\
\hline Land cultivated is downslope (Ref: upslope) & $\begin{array}{l}-0.104 \\
(0.092)\end{array}$ & $\begin{array}{l}0.179 \\
(0.093)^{* *}\end{array}$ & $\begin{array}{l}0.089 \\
(0.091)\end{array}$ & $\begin{array}{l}0.169 \\
(0.092)^{*}\end{array}$ & $\begin{array}{l}0.108 \\
(0.092)\end{array}$ \\
\hline $\begin{array}{l}\text { Land cultivated is in the middle section of the } \\
\text { mountain slopes (Ref: upslope) }\end{array}$ & $\begin{array}{l}-0.030 \\
(0.076)\end{array}$ & $\begin{array}{l}0.138 \\
(0.074)^{*}\end{array}$ & $\begin{array}{l}-0.030 \\
(0.077)\end{array}$ & $\begin{array}{l}0.020 \\
90.076)\end{array}$ & $\begin{array}{l}0.210 \\
(0.083)^{* *}\end{array}$ \\
\hline $\begin{array}{l}\text { Cultivated soils are perceived to be infertile } \\
\text { (Ref: soils are fertile) }\end{array}$ & $\begin{array}{l}-0.194 \\
(0.124)\end{array}$ & $\begin{array}{l}0.245 \\
(0.133)^{*}\end{array}$ & $\begin{array}{l}-0.237 \\
(0.085)^{* *}\end{array}$ & $\begin{array}{l}0.037 \\
(0.129)\end{array}$ & $\begin{array}{l}-0.251 \\
(0.111)^{* *}\end{array}$ \\
\hline $\begin{array}{l}\text { Cultivated soils are perceived to be moderately } \\
\text { fertile (Ref: soils are fertile) }\end{array}$ & $\begin{array}{l}-0.217 \\
(0.078)^{* * *}\end{array}$ & $0.102(0.069)$ & $\begin{array}{l}-0.175 \\
(0.084)^{* *}\end{array}$ & $\begin{array}{l}-0.068 \\
(0.082)\end{array}$ & $\begin{array}{l}-0.303 \\
(0.083)^{* * *}\end{array}$ \\
\hline Access to credit $(1=$ Access, $0=$ No access $)$ & $\begin{array}{l}-0.103 \\
(0.097)\end{array}$ & $\begin{array}{l}0.149 \\
(0.100)\end{array}$ & $\begin{array}{l}0.118 \\
(0.108)\end{array}$ & $\begin{array}{l}-0.023 \\
(0.097)\end{array}$ & $\begin{array}{l}-0.062 \\
(0.106)\end{array}$ \\
\hline $\begin{array}{l}\text { Primary (main) occupation is agriculture } \\
(1=\text { Yes, } 0=\text { No) }\end{array}$ & $\begin{array}{l}0.367 \\
(0.103)^{* * *}\end{array}$ & $\begin{array}{l}-0.080 \\
(0.120)\end{array}$ & $\begin{array}{l}-0.089 \\
(0.127)\end{array}$ & $\begin{array}{l}-0.020 \\
(0.119)\end{array}$ & $\begin{array}{l}0.118 \\
(0.116)\end{array}$ \\
\hline $\begin{array}{l}\text { Distance to nearest market is over } 1 \mathrm{~km} \text { but does } \\
\text { not exceed } 3 \mathrm{~km} \text { (Ref: Distance }<1 \mathrm{~km})\end{array}$ & $\begin{array}{l}0.091 \\
(0.088)\end{array}$ & $\begin{array}{l}0.025 \\
(0.084)\end{array}$ & $\begin{array}{l}0.135 \\
(0.093)\end{array}$ & $\begin{array}{l}0.047 \\
(0.093)\end{array}$ & $\begin{array}{l}-0.033 \\
(0.102)\end{array}$ \\
\hline $\begin{array}{l}\text { Distance to nearest market is over } 3 \mathrm{~km} \\
\text { (Ref: Distance }<1 \mathrm{~km} \text { ) }\end{array}$ & $0.029(0.080)$ & $\begin{array}{l}-0.074 \\
(0.069)\end{array}$ & $\begin{array}{l}0.147 \\
(0.080)^{*}\end{array}$ & $\begin{array}{l}0.114 \\
(0.081)\end{array}$ & $\begin{array}{l}0.171 \\
(0.086)^{*}\end{array}$ \\
\hline Observations & 240 & 240 & 240 & 240 & 240 \\
\hline Wald $\mathrm{chi}^{2}$ & 26.42 & 34.23 & 33.72 & 30.64 & 50.79 \\
\hline Prob $>$ chi $^{2}$ & 0.048 & 0.005 & 0.006 & 0.015 & 0.000 \\
\hline Pseudo $\mathrm{R}^{2}$ & 0.078 & 0.117 & 0.127 & 0.091 & 0.212 \\
\hline Log pseudolikelihood & -150.37 & -129.14 & -137.26 & -148.79 & -130.28 \\
\hline Percent correctly predicted & 58.02 & 26.72 & 34.87 & 42.80 & 47.55 \\
\hline
\end{tabular}

Note: $* * * * *$ and $*$ represent statistical significance at $1 \%, 5 \%$ and $10 \%$ levels, respectively.

\subsection{Determinants of Adoption of Trees}

The probit model for identifying determinants of tree adoption was statistically significant at $5 \%$. Three factors were found to positively and significantly influence the decision to adopt trees: steepness of cultivated land; size of land owned (hectares); and diversity of farm tools owned by the farmer (Table 2). According to the model estimates, the probability of adopting trees is about $17 \%$ higher for farmers whose farmlands are on gentle slopes (downslope) than for those whose farms are on very steep slopes (upslope). It was noted from the survey that 35\% of the farmers cultivated very steep slopes and therefore, they ought to be encouraged to plant trees in order to complement or stabilize other soil erosion control structures. Every additional unit of the square root of the number of types of farm tools (above the mean number of types of tools), increases the probability of adopting 
trees by $17.6 \%$. Thus, it is expected that every unit increase in the types of farm tools will also affect adoption of trees positively and significantly. An additional hectare of land above the mean land size (1.09 ha) increases the probability of adopting trees by $8 \%$. This suggests that increased farmers' acquisition of land can increase adoption of trees. Pender et al. (2004) also found that households that were poorer in terms of ownership of physical assets such as land were less likely to adopt land management practices. A negative and significant relationship was noted between adoption of trees and spending many hours daily on farming activities. An additional increase in the number of hours spent daily on farming activities was likely to reduce the probability of tree adoption by $20.7 \%$. This is perhaps because for farmers who spend over six hours in the farms, tree planting would be additional activity to their busy schedule that they might not easily accept.

\subsection{Determinants of Adoption of Napier Grass}

The model estimates presented in Table 2 for the determinants of Napier grass adoption was statistically significant at $1 \%$, meaning it very well fits the data. The following factors were found to positively and significantly affect the decision to adopt Napier grass: access to extension services; number of different types of farm tools owned, distance to markets; and mid-slope location of farmland along the mountain slopes. The probability of adopting Napier grass increases by about $42 \%$ for each additional type of farm tools owned by the farmer above the mean number of types of tools owned. This is partly because planting of Napier grass requires different farm tools, for example, a panga for preparing the cuttings (planting materials), wheel barrow for transporting the cuttings to the farm, and hoe for digging the holes. In a similar study done in Katakwi district in eastern Uganda, Boyd et al. (2000) found a positive correlation between access to farm tools and investment in soil and water conservation. Unexpectedly, relative to farmers who reside closer to markets, those who are resident at a distance of over $3 \mathrm{~km}$ are $17 \%$ more likely to adopt Napier grass. Distance to markets is used as a proxy for market access and the findings suggest that longer distances (less market access) increase the likelihood of adoption of Napier grass. The probability of adopting Napier grass is $25.6 \%$ higher for farmers with access to extension services than for those without access. This is because it is through extension visits that farmers gain information about improved technologies. Doss (2003) concurs that famers must have access to information about improved technologies before they can consider adopting them. The probability of adopting contours is $21 \%$ higher for farmers whose farmlands are within the middle section of the mountain slopes than for those whose farms are upslope.

On the other hand, there was a negative and significant relationship between adoption of Napier grass and perceived soil fertility and sex. The probability of adopting Napier grass is $30 \%$ lower for farmers with a perception that their soils are moderately fertile than for those who perceive their soils as fertile. Similarly, the probability of adopting Napier grass is $25 \%$ lower for farmers with a perception that their soils are not fertile than for those who perceive their soils as fertile. In short, farmers with relatively less fertile soils are less likely to adopt Napier grass. Yet, it is less fertile soils that mostly require replenishment through use of soil and water conserving technologies. The probability that a male farmer will adopt Napier grass is about $22 \%$ lower than that of a female farmer. These findings again emphasize the need for further extension advice to all farmers, to increase and sustain the fertility of their soils through adoption of soil erosion control technologies.

\subsection{Determinants of Intensity Adoption of Soil Erosion Control Technologies}

The Wald $x^{2}$ of 88.09 is highly significant $(\mathrm{P}=0.00)$ implying that the model is a good fit. The intensity of use of soil erosion control technologies conditional on adoption is significantly influenced by only one factor possession of knowledge regarding the costs and benefits associated with the use of the technologies (Table 3). Conditional on having decided to adopt soil erosion control technologies, farmers who understand the costs and benefits of using these technologies are more likely to use them on proportionally more land than those who do not fully understand the associated costs and benefits. 
Table 3. Relative importance of factors affecting intensity of adoption of soil erosion control technologies

\begin{tabular}{|c|c|c|c|}
\hline & Coefficient & $\begin{array}{c}\text { Robust Standard } \\
\text { Error }\end{array}$ & P Value \\
\hline Years of formal schooling & -0.708 & 0.683 & 0.300 \\
\hline lnAge (years) & 4.813 & 7.868 & 0.541 \\
\hline lnNumber of adults in a household & 0.310 & 4.887 & 0.949 \\
\hline sqrtNumber of different types of farm tools owned & 4.942 & 5.165 & 0.339 \\
\hline lnNumber of daily farming hours & -6.694 & 6.411 & 0.296 \\
\hline lnSize (hectares) of land owned & -2.543 & 2.584 & 0.325 \\
\hline Sex $(1=$ Male, $0=$ Female $)$ & 8.201 & 6.212 & 0.187 \\
\hline Access to extension services ( $1=$ Access, $0=$ No access $)$ & -5.349 & 4.379 & 0.222 \\
\hline Land cultivated is downslope (Ref: upslope) & 7.952 & 5.885 & 0.177 \\
\hline \multicolumn{4}{|l|}{ Land cultivated is in the middle section of the mountain slopes } \\
\hline (Ref: upslope) & 2.194 & 4.667 & 0.638 \\
\hline Cultivated soils are perceived to be infertile (Ref: soils are fertile) & -3.672 & 7.818 & 0.639 \\
\hline Cultivated soils are perceived to be moderately fertile (Ref: soils are fertile) & -6.818 & 4.665 & 0.144 \\
\hline Primary (main) occupation is agriculture ( $1=$ Yes, $0=$ No) & 10.752 & 6.801 & 0.114 \\
\hline Distance to nearest market is over $1 \mathrm{~km}$ but does not exceed $3 \mathrm{~km}$ & & & \\
\hline (Ref: Distance <1 km) & -4.312 & 5.961 & 0.469 \\
\hline Distance to nearest market is over $3 \mathrm{~km} \quad$ (Ref: Distance $<1 \mathrm{~km}$ ) & -8.495 & 5.314 & 0.110 \\
\hline Has knowledge of costs \& benefits associated with making contours & 20.728 & 5.401 & 0.000 \\
\hline Has knowledge of costs \& benefits associated with planting of Napier grass & -6.531 & 5.560 & 0.240 \\
\hline Has knowledge of costs \& benefits associated with tree planting & -8.154 & 4.733 & 0.085 \\
\hline Has knowledge of costs \& benefits associated with making terraces & 7.261 & 5.005 & 0.147 \\
\hline Has knowledge of costs \& benefits associated with digging trenches & 19.954 & 5.248 & 0.000 \\
\hline Observations & 240 & & \\
\hline Wald chi ${ }^{2}$ & 88.09 & & \\
\hline Prob $>\mathrm{chi}^{2}$ & 0.000 & & \\
\hline Log pseudolikelihood & -1166.26 & & \\
\hline Percent linear prediction & 62.73 & & \\
\hline
\end{tabular}

\section{Conclusions and Recommendations}

Most farmers around Mt. Elgon are taking measures to control soil erosion. They are combining soil erosion control technologies in several ways but some farmers are using only one type of technology. Contours and strips of Napier grass are the most commonly practiced technologies. The degree of use of soil erosion control technologies varies from farmer to farmer. However, on average, adopters are applying the technologies to about $70 \%$ of the cultivated land. Although the intensity of technology adoption is generally reasonably high, there are farmers who are using the technologies on smaller scales. From the foregoing, we conclude that more effort is needed to ensure that all farmers begin to use soil erosion control technologies and on full scale.

Based on the probit model estimates, we note that factors that can positively and significantly increase the likelihood of adopting soil erosion control technologies are: access to relevant agricultural extension services; ownership of many different types of farm tools ( $>3$ types); and ownership of relatively much land ( $>1.09$ hectares). Once the farmer has made a decision to adopt soil erosion control technologies, the most important factor that will positively and significantly affect the degree of technology use is possession of knowledge of the costs and benefits associated with the use of the technologies. On the negative side, we note that farmers who are 
of the opinion that their soils are either not fertile or just moderately fertile, are less likely to adopt soil erosion control technologies compared with farmers with the perception that their soils are fertile.

Based on the findings we recommend that programs such as the National Agricultural Advisory Services (NAADS) should reach out to many farmers, for example, by increasing the number of Agricultural Service Providers and facilitating them to conduct trainings. Already, programs such as NAADS and the Northern Uganda Social Action Fund not only provide advisory services but also give farmers free farm inputs, including farm implements. Thus, we recommend that such efforts be extended to farmers who lack tools that would otherwise enable them adopt different soil erosion control technologies. Also, the costs and benefits of using soil erosion control technologies should be estimated, documented and disseminated to farmers by the National Agricultural Research Systems (NARS) and other researchers. Since adoption of some technologies is affected by land size, we suggest that as Government continues to resettle people who were evicted from Mt. Elgon National park, each household should be given at least one hectare of land. We strongly recommend that farmers, especially those who perceive their soils to be less fertile to begin to seek and use extension advice on how to replenish and sustain soil fertility. Indeed, the theoretical underpinning of the NAADS programme design was to empower farmers to demand and control agricultural advisory services.

\section{Acknowledgements}

The authors gratefully acknowledge the financial support from the Regional Universities Forum for Capacity Building in Agriculture (RUFORUM), Association for Strengthening Agricultural Research in Eastern and Central Africa (ASARECA) and African Highlands Initiative (AHI).

\section{References}

Agresti, A. (2002). Categorical Data Analysis (2nd ed.). New York, NY: Wiley \& Sons. http://dx.doi.org/10.1002/0471249688

Amemiya, T. (1981). Qualitative response models: A survey. Journal of Economics Literature, 19(4), 1483-1536. http://dx.doi.org/10.2307/1241687

Antle, J. M. (1987). Econometric estimation of producers' risk attitudes. American Journal of Agricultural Economics, 69(3), 509-522.

ASARECA (Association for Strengthening Agricultural Research in Eastern and Central Africa). (2004). Natural resources management for agriculture in Eastern and Central Africa 2005-2015. Kampala, Uganda.

Atemnekeng, T. J., Boboh, M. V., \& Kenyi, D. M. (2011). Adoption of Maize and Cassava Production Technologies in Forest Savannah Zone of Cameroon: Implications for Poverty Reduction. World Applied Sciences Journal, 11(2), 196-209. IDOS Publications.

Bellone, T., Boccardo, P., \& Perez, F. (2009). Investigation of Vegetation Dynamics Using Long-Term Normalised Difference Vegetation Index Time-Series. American Journal of Environmental Sciences, 5(4), 460-466. http://dx.doi.org/10.3844/ajessp.2009.461.467

Binswanger, H. P. (1980). Attitudes Toward Risk, Experimental Measurement in Rural India. American Journal of Agricultural Economics, 62(3), 395-407. http://dx.doi.org/10.2307/1240194

Boyd, C., \& Turton, C. (2000). The contribution of soil and water conservation to sustainable livelihoods in semi-arid areas of Sub-Saharan Africa. Agricultural Research and Extension Network (AgREN). Paper No. 102. ODI (Overseas Development Institute). Retrieved from http://www.odi.org.uk/sites/odi.org.uk/files/odi-assets/publications-opinion-files/5124.pdf

Coady, D. P. (1995). An empirical analysis of fertilizer use in Pakistan. Economica, 62(246), 213-234. http://dx.doi.org/10.2307/2554904

Cragg, J. (1971). Some statistical models for limited dependent variables with application to the demand for durable goods. Econometrica, 39, 829-844. http://dx.doi.org/10.2307/1909582

Dillon, J. L., \& Pasquale, L. S. (1978). Risk attitudes of subsistence farmers in Northeast Brazil: A sampling approach. American Journal of Agricultural Economics, 60(3), 425-435. http://dx.doi.org/10.2307/1239939

Doss, C. R. (2003). Understanding farm level technology adoption: Lessons from CIMMYT's micro surveys in Eastern Africa. CIMMYT Economic working paper 03-07. Mexico, D.F.

FAO (Food and Agriculture Organization of the United Nations). (2006). Eradicating World Hunger - Taking stock ten years after the World Food Summit: The State of Food Insecurity in the World. FAO, Rome. 
Feder, G., Just, R. E., \& Zilberman, D. (1985). Adoption of agricultural innovations in Developing Countries: A Survey. Economic Development and Cultural Change, 33(2), 255-298. http://dx.doi.org/10.1086/451461

Feder, G., \& O'Mara, G. T. (1981). Farm size and diffusion of green revolution technology. Economic Development and Cultural Change, 30(1), 59-76. http://dx.doi.org/10.1086/452539

Fowler, T. J. (1998). Design and Evaluation of Survey Questions. In L. Birkman, \& D. J. Rog (Eds.), Handbook of Applied Social Research Methods, (pp. 343-374). Thousand Oaks: Sage.

Greene, W. H. (1997). Econometric Analysis. (4th ed.) Prentice-Hall, Inc. New York.

Greiner, R., Patterson, L., \& Miller, O. (2009). Motivations, risk perceptions and adoption of conservation practices by farmers. Agricultural systems, 99, 86-104. http://dx.doi.org/10.1016/j.agsy.2008.10.003

Hamilton, P. (1997). Goodbye to Hunger! The adoption, diffusion and impact of conservation farming practices in rural Kenya. Association for better land husbandry, Report No. 12, Nairobi, Kenya.

Harper, J. K., Rister, M. E., Mjelde, J. W., Dress, B. M., \& Way, M. O. (1990). Factors influencing the adoption of insect management technology. American Journal of Agricultural Economics, 72(4), 997-1005. http://dx.doi.org/10.2307/1242631

Hatibu, N. (2005). Scaling up and uptake promotion and soil and water management research outputs in East and Central Africa: Constraints and Barriers. Discussion Paper 4.

Hellin, J. (2003). From soil erosion to soil quality. LEISA Magazine, 19(4).

Henao, J., \& Baanante, C. (2006). Soil nutrient mining in Africa Report. Agricultural production and soil nutrient in Africa. Implication for resource conservation and policy development. International Centre for Soils fertility and Agricultural development.

IFPRI (International Food Policy Research Institute). (2007). Assessing the Impact of the National Agricultural Advisory Services (NAADS) in the Uganda Rural Livelihoods. Discussion Paper 00724.

IMF (International Monetary Fund). (2006). World Economic Outlook Database: financial systems and economic cycles. Washington, DC.

Jansky, L., \& Chandran, R. (2004). Climate change and sustainable land management: Focus on erosive land degradation. Journal of the World Association of Soil and Water Conservation, 4, 17-29.

Jensen, H. H., \& Yen, S. T (1996). Determinants of household expenditures on alcohol. Journal of Consumer Affairs, 30(1), 48-67. http://dx.doi.org/10.1111/j.1745-6606.1996.tb00725.x

Kashay, T. (2011). The effect of land tenure systems on soil conservation practices in Northern Ethiopia. A case study of Habru District in Amhara National Regional State (ANRS), Ethiopia. Kimmage Development Studies Centre (DSC).

Keeley, J. E. (2001). Influencing Policy Processes for Sustainable Livelihoods: strategies for change. Lessons for Change in Policy \& Organisations, No. 2. Institute of Development Studies, Brighton.

Kilewe, A. M., \& Hatibu, N. (2004). Institutionalized scaling up and uptake promotion of outputs soil and water management in East and Central Africa. SWMnet Discussion Paper 3.

Langyintuo, A. S., \& Mungoma, C. (2008). The effect of household wealth on the adoption of improved maize varieties in Zambia. Food Policy, 33, 550-559. http://dx.doi.org/10.1016/j.foodpol.2008.04.002

Lufumpa, C. (2005). The poverty-environment nexus in Africa. African Development Review, 17(3), 366-381. http://dx.doi.org/10.1111/j.1017-6772.2006.00120.x

MAAIF (Ministry of Agriculture, Animal Industry and Fisheries). (2010). Agriculture Sector Development Strategy and Investment Plan: 2010/11-2014/15. Agriculture for Food and Income Security. Republic of Uganda.

MAAIF (Ministry of Agriculture, Animal Industry and Fisheries). (2011). Statistical Abstract.

Manyong, V. M., Houndékon, V. A., Sanginga, P. C., Vissoh, P., \& Honlonkou, A. N. (1999). Mucuna Fallow Diffusion in Southern Benin. International Institute of Tropical Agriculture.

Mati, B. M. (2005). Overview of water and soil nutrient management under smallholder rain-fed agriculture in East Africa. Working paper No. 105. International Water Management Institute (IWMI), Colombo, Sri Lanka.

MFPED (Ministry of Finance, Planning and Economic Development). (2000). Plan for modernization of 
agriculture (PMA): Eradicating poverty in Uganda. Kampala, Uganda.

Montgomery, M. R., Kiros, G. E., Agyeman, D., Casterline, J. B., Aglobitse, P., \& Hewett, P. C. (2001). Social networks and contraceptive dynamics in Southern Ghana. Policy Research Division Working Paper 153, New York: Population Council.

Moscardi, E., \& de Janvry, A. (1977). Attitudes toward risk among peasants: an econometric approach. American Journal of Agricultural Economics, 59(4), 710-716. http://dx.doi.org/10.2307/1239398

Mowo, J. G., Mwihomeke T. S., \& Mzoo J. B. (2002). Managing natural resources in the West Usambara Mountains: A glimmer of hope in the horizon. Paper Presented at the Mountain High Summit Conference for Africa, 6-10 May 2002, Nairobi. UNEP.

Nakhumwa, T. O. (2004). Dynamic costs of soil degradation and determinants of adoption of soil conservation technologies by smallholder farmers in Malawi. PhD thesis, University of Pretoria, South Africa.

NEMA (National Environment Management Authority). (2001). Uganda State of the Environment Report 2000 Version 2. Ministry of Natural Resources, Government of Uganda. Kampala, Uganda.

Nkonya, E., Pender, J., Kaizzi, C. K., \& Kato, E. (2008). Linkages between Land Management, Land Degradation, and Poverty in Sub-Saharan Africa. The Case of Uganda. IFPRI Report 159. International Food Policy Research Institute.

Nkonya, E., Pender, J., Kaizzi, C., Kato, E., \& Mugarura, S. (2005a). Policy options for increasing crop productivity and reducing soil nutrient depletion and poverty in Uganda. IFPRI, Washington, D.C.

Olson, J., \& Berry, L. (2003). Land Degradation in Uganda: Its Extent and Impact. Land Degradation Assessment in Dry lands (LADA).

Olwande, J., Sikei, G., \& Mathenge, M. (2009). Agricultural technology adoption: A panel analysis of smallholder farmers' fertiliser use in Kenya. Contributed paper for presentation at the African Economic Research Consortium Conference on Agriculture for Development, May $28^{\text {th }}-29^{\text {th }}$, Mombasa, Kenya.

Pender, J., Nkonya, E., Jagger, P., Sserunkuuma, D., \& Ssali, H. (2004). Strategies to increase agricultural productivity and reduce land degradation: evidence from Uganda. Agricultural Economics, 31(2/3), 181-195.

Sachs, J. D., McArthur, J. W., Schmidt-Traub, G., Kruk, M., Bahadur, C., Faye, M., \& McCord, G. (2004). "Ending Africa's Poverty Trap," Brooking papers on Economic Activity, 2, 117-216.

Sanchez, P. (2002). Soil Fertility and Hunger in Africa. Science, 295, 2019-2020. http://dx.doi.org/10.1126/science.1065256

Slade, G., \& Weitz, K. (1991). 'Uganda: Environmental issues and options'. Center for Resource and Environmental Policy Research Working Paper No. 91-3. School of Forestry and Environmental Studies, Duke University.

Ssewanyana, S., \& Kasirye, I. (2010). Food insecurity in Uganda: a dilemma to achieving the hunger millennium development goal. Economic Policy Research Centre (EPRC) Research series No. 70., Kampala Uganda.

StataCorp. (2011). Stata Statistical Software: Release 12. College Station, TX: StataCorp LP.

Thomas, D. B. (1997). Soil and water conservation Manual for Kenya. Ministry of Agriculture, Livestock Development and Marketing. Nairobi, Kenya.

Thomas, D. B., \& Baimah, E. K. (1991). Origin, application and design of Fanya juu terraces. In W. C. Moldenhauer, N. W. Hudson, T. C. Sheng, \& Swa-Wei Lee, (Eds.), Development of conservation farming for hill slopes. Soil and water conservation society, Ankey, Iowa, USA: 185-194. Soil and water conservation society.

Troeh, F. R., Hobbs, J. A., \& Donahue, R. L. (1999). Soil and water conservation: productivity and environmental protection. (3rd ed.). Prentice Hall.

UNPF (United Nations Population Fund). (2007). State of world population 2007. Retrieved from http://www.unpfa.org/swp/swpmain.htm

Wooldridge, J. M. (2009). Introductory Econometrics (4th ed.). South-Western Cengage Learning.

World Bank. (2007). World Bank Development Report 2008. Agriculture for development. Washington, DC: 
World Bank. http://dx.doi.org/10.1596/978-0-8213-6807-7

World Rainforest Movement (WRM). (2008). WRM's bulletin No. 131, June 2008. Retrieved from http://www.wrm.org.uy/bulletin/131/Uganda.html

Yaron, D., Dinar, A., \& Voet, H. (1992). Innovations on family farms: The Nazareth Region in Israel. American Journal of Agricultural Economics, 361-370. http://dx.doi.org/10.2307/1242490

Yen, S., \& Jones, A. (1997). Household consumption of cheese: An inverse hyperbolic sine double-hurdle model with errors. American Journal of Agricultural Economics, 79, 246-251. http://dx.doi.org/10.2307/1243958

Yila, O. M., \& Thapa, G. B. (2008). Adoption of agricultural land management technologies by smallholder farmers in Jos plateau, Nigeria. Earthscan.

Yirga, C. (2006). The Dynamics of soil degradation and incentives for optimal management in the central highlands of Ethiopia. PhD thesis, University of Pretoria, South Africa.

Zake, J. S., Nkwiine, C., \& Magunda, M. K. (1999). Integrated Soil Management for Sustainable Agriculture and Food Security in Southern and East Africa. In H. Nabhan, A. M. Mashali, \& A. R. Mermut (Eds.). Proceedings of the Expert Consultation Conference, Harare, Zimbabwe. Food and Agriculture Organization of the United Nations.

Zimmermann, R., Brüntrup, M., Kolavalli, S., \& Flaherty, K. (2009). Agricultural Policies in Sub-Saharan Africa. Understanding CAADP and APRM Policy Processes. The German Development Institute. 